\title{
Evaluating The Strategic Implications Of Japanese IT Offshore Outsourcing In China And India
}

Roblyn Simeon, San Francisco State University, USA

\begin{abstract}
Many studies have been done on the market, managerial and technological factors that impact IT outsourcing decisions. However, few of these studies have looked at institutional and cultural factors influencing various approaches to outsourcing. Developments in Japanese IT software outsourcing make it an excellent sector for studying the impact of such institutional and cultural factors. This qualitative study looks at the contrasting motivations behind IT outsourcing to India and China in order to gain insights into what the Japanese firms consider the key success factors for IT software offshore outsourcing. Preliminary indications are that old business relations, trust, language requirements, cultural similarity and the ability to capture certain idiosyncratic business practices and routines are essential factors driving Japanese IT outsourcing decisions.
\end{abstract}

Keywords: Japanese Outsourcing, India, China, Emerging Markets, Information Technology

\section{INTRODUCTION}

$\mathfrak{d}$ he outsourcing phenomenon represents one of the most fundamental developments in global business strategies. As globalization accelerates and competition intensifies, outsourcing has become a strategic solution for many corporations and governments around the world. Consequently, there has been a lot of research done on the impact of and approaches to outsourcing. However, the majority of this research has focused on market, managerial and technological motivations for outsourcing strategies. Generally, these studies examine the determinants for the pace, duration, location, and impact of outsourcing activities.(Hall 2000; Gottschalk and Solli-Sæther 2005; Gottschalk and Solli-Sæther 2006)

Few of these studies have been carried out on the institutional factors impacting the various approaches to outsourcing. These institutional factors include the importance of regulations, corporate culture, and embedded business relationships. Developments in Japanese IT outsourcing make it an excellent sector for studying the impact of institutional factors on outsourcing approaches. Embedded relationships, regulations and corporate culture have all played a significant role in Japanese IT outsourcing (Farrell 2005; McCoy 2006; Montes and Kleiner 2007).

However, in order to understand the implications of Japanese outsourcing behavior, it is important to clarify the relationship between outsourcing in general and offshoring practices. McFarlan and Delacey point out that outsourcing refers to the contracting of independent third parties to execute well-defined business processes or services. This can take place in the local environment or elsewhere. On the other hand, offshoring refers to the moving of business processes to other countries - either by establishing an offshore subsidiary or contracting with an established firm to handle the outsourced process (King 2005; Koong, Liu et al. 2007) (McFarlan and Delacey, 2004) . This paper will focus on offshore outsourcing of software development by Japanese firms.

Since the 1990's, many Japanese companies have chosen to outsource all or large parts of their information technology system development and/or management in order to reduce costs and improve the quality of their systems. This paper examines the combined processes of "offshore outsourcing" in which companies contract third parties in other counties to execute certain business processes. The main purpose of this paper is to clarify which 
market and institutional factors dominate Japanese IT-software offshore outsourcing decisions by doing a comparative analysis of China and India as offshore outsourcing locations. This qualitative exploration should also provide some insights into the future direction of Japanese IT software outsourcing.

\section{MARKET CHARACTERISTICS OF JAPANESE IT-SOFTWARE INDUSTRY}

Japan has the second largest IT market in the world after the US. The total size of Japan's information services industry in 2005 was about 14.5 trillion Yen (US\$124 billion). The industry employed about 600,000 people in 2003 (Ministry of Economy, Trade and Industry, Japan, 2004). Five giants (Fujitsu, IBM, NEC, Hitachi, and NTT Data) drive the industry. Their combined market share (consolidated number among group companies) reaches more than $50 \%$ of the IT service and software market. Around 5,600 other companies make up the rest of the 50\% (Yamanoi, 2004).

After the IT boom in 1995-2001, the growth of the Japanese IT industry slowed dramatically. Total revenues increased by only $0.2 \%$ from 2004 to 2005 due to a number of factors. First, the sluggish Japanese economy caused Japanese companies to be hesitant to invest in IT. Moreover, since Japanese firms have to spend $85 \%$ of their IT-related budget for the operation and maintenance of current systems, they have only $15 \%$ of resources to dedicate to new technology (Atmark IT, 2005).

The slower growth resulted in fierce competition and a downward pressure on price. Vendors often lowered the price at the expense of profitability in order to get long-term contracts. Many of the companies were hoping to recoup their losses from after-sale service contracts such as the support and upgrading of their IT systems.

Software development is a critically important part of the Japanese IT sector. The software developers can be categorized into three groups - Maker, User, and Independent System Integrator (so-called SIer). The Maker group consists of computer manufacturers and their subsidiary companies which provide total system solutions including software development and support as well as hardware. Representative companies are Fujitsu, NEC, Hitachi and IBM. Companies in the User group are former IT divisions which were spun off from parent "user" companies in order to transform themselves into profit centers from cost centers. Most of the large players in financial, manufacturing, and trading sectors keep vertical relationships with their IT subsidiary companies. Some of those spin-offs expanded their business to get contracts with other companies. Independent system integrators (SIers) do not have parents companies unlike companies of the Maker and User groups. They sometimes work as subcontractors for other IT companies in the Maker and User groups. (Atmark IT, 2005) (Tomiura 2005; Nagayama 2006)

As we can see in Figure 1, custom software development accounts for as much as $47 \%$ of Japanese IT software industry's total revenue. Since half of the software products category is made up of game software and basic software for computers, business software products accounts for only 5\% of total revenue (METI, Japan, 2004).

Another characteristic of Japanese IT is the use of embedded software. Embedded software is built into and used in various electronic products such as digital appliances, cell phones, industrial equipments, and vehicles. Recently, more and more electronics are controlled by embedded software and their functions have become increasingly important and complex. The advancement in networking technology, cheaper and smaller hardware memories, and fast product cycles have accelerated the demand for embedded software. The new cell phone models have many functions such as camera, text messaging, wireless internet, music player, PC synchronization, PDA, bill payment, and GPS. The embedded software used in these cell phones is comprised of more than 10 million lines of code (Asami, 2007). 
Figure 1: Annual Sales by Category of Business

\begin{tabular}{|c|c|} 
Annual sales by category of business \\
$\begin{array}{c}\text { Custom Softw are } \\
\text { Development } \\
47 \%\end{array}$
\end{tabular}

According to the estimates of the Japanese Ministry of Internal Affairs and Communications, the market for embedded software development is 2730 billion Yen (\$25.4 billion). Although the number of Japanese engineers specialized in embedded software development is about 193,000, the Japanese Ministry of Economy, Trade and Industry (METI) estimates a potential shortfall of 94,000 engineers for this industry (METI, 2006).

\section{INSTITUTIONAL CHARACTERISTICS OF THE JAPANESE IT-SOFTWARE SECTOR}

Institutional factors refer to a wide range of activities. Industry regulations, embedded relationships and old-style operating practices are all characteristic of the Japanese IT-software sector. In general, Japanese firms prefer custom software over off-the-shelf packages. One of the main reasons is a tendency to stick to the traditional ways of doing business. They are concerned that they might lose specific competencies by standardizing their special business processes. This desire to maintain unique business practices and routines impedes the effort to adapt package software that would streamline business processes and IT systems. In addition, package software often forces organizations to change the style of business transactions between their customers and business partners. As a result, companies choose to develop custom software which basically reproduces the needs of current operations (ITPro, 2007).

The nature of business contracts, the use of Japanese language and long-term close relationship between customers and vendors are all factors that impact Japanese IT offshore-outsourcing practices. Since project specifications and contracts are not well defined or documented in the early stages, vendors have to modify the application over and over again during the development process. Vendors are required to read between the lines of poorly-defined specifications and sense the real requirements of clients. This kind of over-dependency on vendors is attributable to the long-term "keiretsu" relationships in the Japanese business environment. Since the vendors generally belong to the same business group, they are expected to completely understand the client's practices and offer the optimum IT systems. Quite often, these unique relationships have prevented them from adopting more efficient and standardized project management styles and methods.(Tomiura 2005; Waldenberger 2007)

In Japan, there are serious concerns about the labor shortage in many industries due to the falling birthrate and the aging population. For many firms, it has become more difficult to secure new graduates who can support their companies far in the future. To make things worse, IT-related jobs are becoming less popular among new graduates mainly because of the long working-hours. Some call it "3K job" - Kitsui (hard), Kaerenai (cannot go home), and Kyuryo ga yasui (cheap salary) (Tech Soken, 2007). When companies cannot hire enough capable workers, the current staff has to work even longer hours, which could eventually result in higher employee turnover. 
Another area of concern is that many IT companies will eventually lose a lot of managers with large project experience. Most younger engineers do not have knowledge of old technologies, while a lot of companies still use "legacy" systems such as mainframe computers. After the baby boomers retire, IT companies might not be able to secure enough engineers to support their clients' old systems. The older specialists know how the many different technologies have been put together to make the system work and they are aware of the kind of relationships that have been established with their clients. Most of this embedded knowledge and relationships have not been fully shared with younger. All these factors could eventually lead to a scarcity of young capable workers at the same time that there is mass retirement of experienced managers.

\section{JAPANESE APPROACH TO IT-SOFTWARE OUTSOURCING}

More and more Japanese companies are interested in offshore-outsourcing of software development. About one forth of Japanese IT companies have outsourced part of their operations overseas, and more are interested in doing so. Based on the estimation by JISA (Japan Information Technology Services Industry Association), the market size of offshore development is more than $\$ 1.6$ billion in 2002 (JISA, 2003). According to the estimation by Japanese Ministry of Internal Affairs and Communications, it could reach 200 billion Yen ( $\$ 1.9$ billion) by 2010 (Ministry of Internal Affairs and Communications, Japan, 2007). Japanese IT outsourcing practices has several unique characteristics which are resulted from the distinctive aspects of Japanese IT industry.

The number of Japanese companies which outsource IT software development to foreign countries is increasing. According to Table 1 which is based on the survey conducted by JEITA, JPSA, and JISA, about one fourth of IT companies have outsourced part of their software development overseas by 2004 (JEITA, JPSA, and JISA, 2005).

Table 1: Outsourcing Ratios

\begin{tabular}{|l|c|c|c|}
\hline & $\mathbf{2 0 0 2}$ & $\mathbf{2 0 0 3}$ & $\mathbf{2 0 0 4}$ \\
\hline Outsourced & $22.14 \%$ & $23.11 \%$ & $24.21 \%$ \\
Did not Outsource & $77.86 \%$ & $76.89 \%$ & $75.79 \%$ \\
\hline
\end{tabular}

Source: JEITA, JPSA, and JISA, 2005

Figure 2 shows that instead of directly dealing with offshore companies, firms are increasingly relying on third party Japanese companies to do outsourcing business. Many companies become more aware of the difficulties of offshore outsourcing after seeing the failure of other companies in this area. Therefore, more managers think it is safer and easier to ask a more experienced third-party to manage offshore development instead of doing it on their own (Figure 2).

Figure 2: Outsourcing Approach

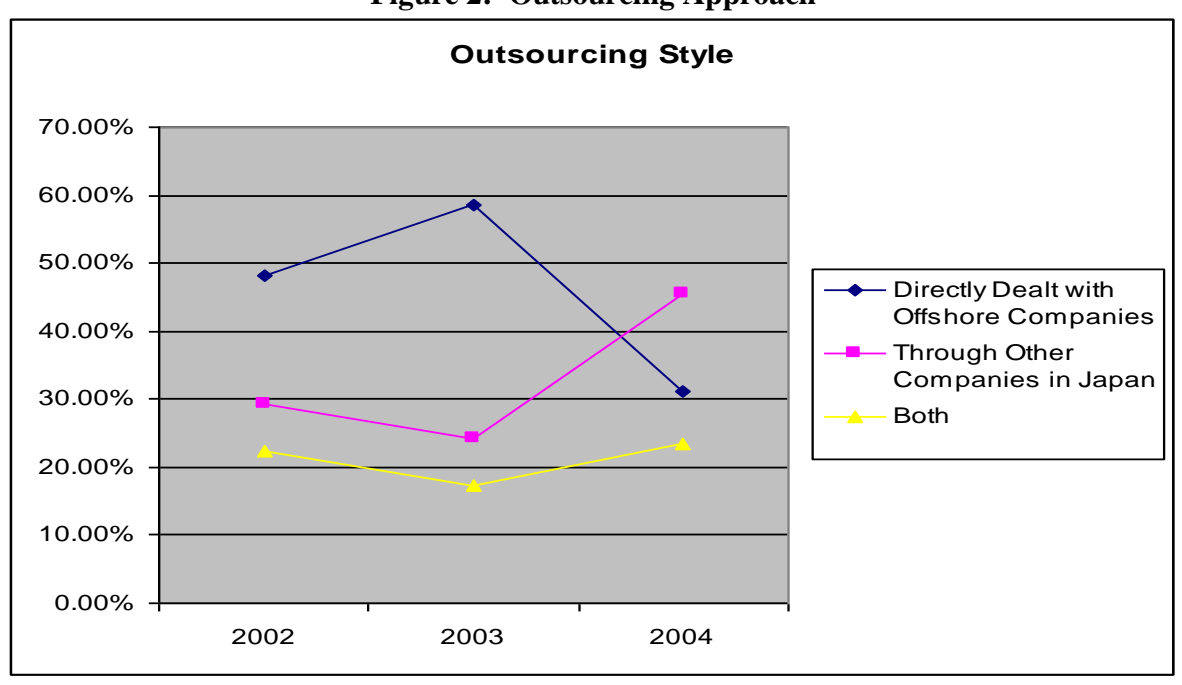

Source: JEITA, JPSA, and JISA, 2005 
We can see in Figure 3 that another Interesting tendency here is that IT companies owned by manufacturers outsource more than the other groups (Independent, User, and Foreign-Capital). The main reason could be the long history and experience of offshore outsourcing of their core business - manufacturing. A lot of Japanese manufactures have built factories and subsidiary companies in China and other countries. Some of the know-how of operations in foreign countries could be transferable to offshore outsourcing of IT system development. They can also leverage the local connection and relationships with government officers to access partners.

Figure 3: Outsourcing Ratio and Type of Capital (2005)

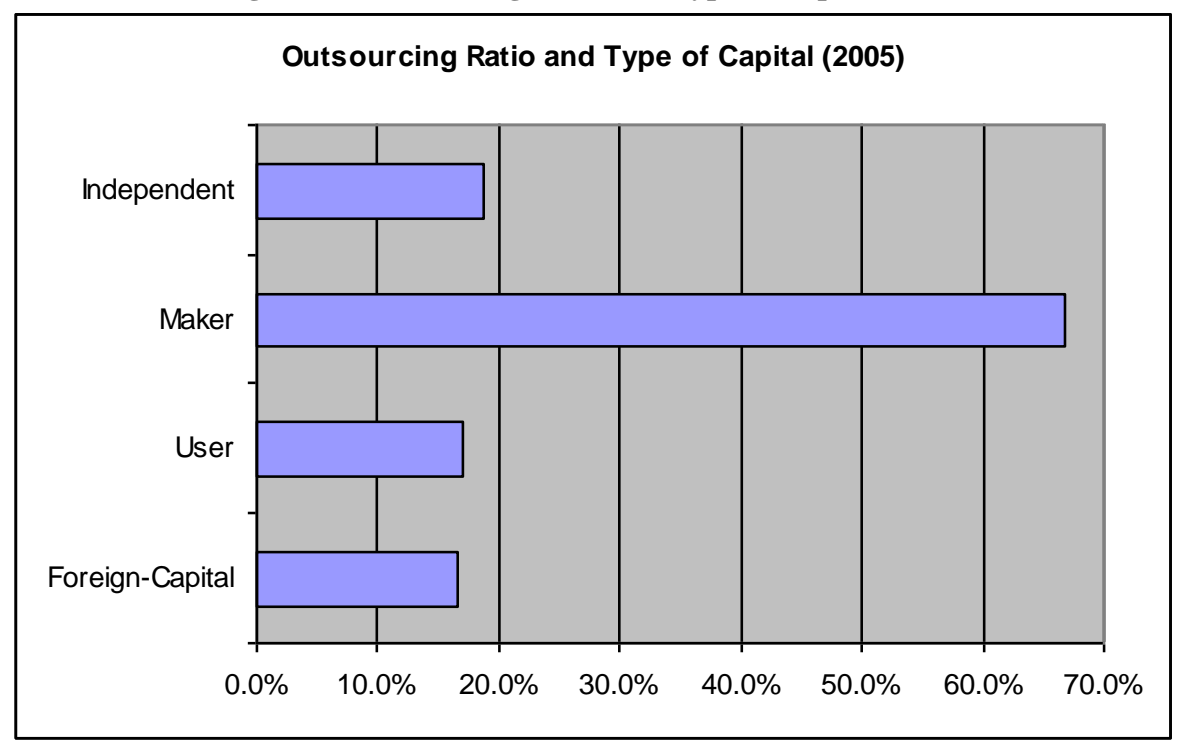

("Maker" category includes computer makers.)

Source: JEITA, JPSA, and JISA, 2005

Despite some peculiar outsourcing practices, when surveyed, Japanese give a variety of rational reasons for outsourcing decisions. The four major rational criteria given by Japanese firms on how they choose offshore vendors are as follows (JEITA, JPSA, and JISA, 2005):

1. Quality and availability of engineers

2. Japanese proficiency

3. $\quad$ Legitimacy of price

4. Track record of business with Japanese companies

Although these criteria sound reasonable, some point out that Japanese companies do not have clearly defined criteria in choosing offshore vendors. In December 2006, Accenture conducted a survey to compare the IT offshore software development utilization capability between Japanese and US companies, on consignment by JEITA. They divided the whole process of offshore development into four steps; Stage1: Internal policy and criteria of offshore development, Stage2: Planning and contracting, Stage3: Management of development, and Stage4: Evaluation. For each step, they evaluated Japanese and US companies and rank them from Level 1 (No definition) to Level 5 (Periodic reexamination of criteria) in terms of how the criteria and the business process are institutionalized in the organization. Japanese companies were ranked lower than US organizations in the all stages of offshore development practices. Japanese companies do not have defined standard and procedure to go through offshore development nor internal systems to improve the operation process. In addition, Japanese companies do not involve offshore vendors until later stage, while US companies involve them from upstream operations such as system planning and designing. US companies which work with offshore vendors as business partners, not as subcontractors, are more likely to build integrated development teams. (JEITA \& Accenture, 2006) 
The software offshore-outsourcing location decisions of Japanese firms generally take into account the business relationships, cultural, and process demands of their operations. By examining the comparative strengths and opportunities of outsourcing to China and India, we can gain a lot of insight into what are the key success factors for Japanese offshore software development.

\section{OUTSOURCING TO CHINA: STRENGTHS \& OPPORTUNITIES}

Based on the data from CSIA (China Software Industry Association), the revenue of Chinese software industry reached 390 billion Yuan ( $\$ 50.7$ billion) in 2005 . It increased by $40.3 \%$ from the previous year. The software export was $7.6 \%$ of the total revenue, reaching 30 billion Yuan ( $\$ 3.9$ billion). The industry employed 900,000 people (JISA, 2006). What makes China the most attractive outsourcing destination for Japanese companies is the large number of Japanese speakers/learners. The language is one of the major concerns Japanese companies because the majority of Japanese employees in the IT industry who are reluctant to do business with foreign partners in English or languages other than Japanese. In 2003, there were about 206,000 formal Japanese learners. That number is 20 times higher than in India. The number of applicants for the Japanese language proficiency test in China was recently more than 165,000 (30\% of total applicants). In addition, about 74,300 Chinese students are learning in Japan as foreign students (about 63\% of the foreign students in Japan) (JASSO, 2006).

Xinhua reported that Dalian has 20,000 people working in the software outsourcing sector and 70 percent of them speak Japanese. In addition, about 40,000 students in Dalian are learning software technologies in five professional institutions and 22 colleges. Half of the students have received Japanese language training and will work for outsourcing business upon graduation" (Xinhua, 2007). After graduation, Chinese foreign students will also play an important role in outsourcing activities with Japan since they know both the language and the culture.

Since the mid 1990's, an underwater cable network has been developed across the Pacific Ocean and in East Asia. The network capacity between Japan and China increased significantly; especially after high-capacity cables were built in East Asia in 2001 and 2002 (Ministry of Internal Affairs and Communications, Japan, 2007). In Table 2, it is clear that the private lines and IP-VPNs (Virtual Private Line) between Japan and China are a lot cheaper and have higher-capacity than the ones between Japan and India.

Table 2: Communication Infrastructure between Japan and China

\begin{tabular}{|l|l|c|c|}
\hline \multicolumn{2}{|c|}{ Total Capacity of Underwater Cable } & Japan-China & Japan-India \\
\hline \multirow{3}{*}{ International Private line } & \# of User companies & $12,930 \mathrm{Gbps}$ & $50 \mathrm{Gbps}$ \\
\cline { 2 - 4 } & Average Capacity per company & 85 & 7 \\
\cline { 2 - 4 } & Usage fee per 64kbps & $82.1 \mathrm{Mbps}$ & $0.59 \mathrm{Mbps}$ \\
\hline \multirow{3}{*}{ International IP-VPN } & \# of User companies & $22,610 \mathrm{Yen}$ & $76,180 \mathrm{Yen}$ \\
\cline { 2 - 4 } & Average Capacity per company & 275 & 19 \\
\cline { 2 - 4 } & Usage fee per 64kbps & $3.6 \mathrm{Mbps}$ & $2.6 \mathrm{Mbps}$ \\
\hline
\end{tabular}

Source: Ministry of Internal Affairs and Communications, Japan, 2007

Japan and China share a long history of cultural interaction. Until the Japanese government decided to close the country in $1600 \mathrm{AD}$, the Japanese learned and adopted a variety of cultural elements, technologies, and political systems from one of the world's earliest civilizations. Therefore, many aspects of Japanese culture such as language components, philology, and art were influenced by Chinese culture. In addition to cultural similarity, having track record of business with Japanese companies is one of the most important criteria when Japanese companies choose offshore vendors. Chinese companies have these advantages because they already have done more IT outsourcing projects with the Japanese. Finally, since Chinese companies in manufacturing sector have experienced outsourcing business with Japanese companies for several decades, they are more familiar with the Japanese management style.

China is geographically close to Japan. It takes only 3-6 hours to fly to major cities in China from Japan. Traveling between Japan and China are becoming easier and more convenient, now that many airlines compete to 
increase the direct flights among major cities in Japan and China. For example, there are as many as 18 direct flights from Tokyo to Shanghai each day, and the flight only takes about 3 hours. Just an hour time difference also makes the business with Chinese partners easy.

Strong domestic demand is a positive factor for Japanese companies considering outsourcing business in China in two ways. First, they can expect that the Chinese government will support the development of the Chinese IT industry. Second, for companies which see China not only as an outsourcing destination, but also as an emerging market, the strong domestic demand is appealing.

If a Japanese outsourcer and its partner in China can offer innovative technologies or services at affordable prices, the Chinese government and domestic businesses could become customers. One such example was reported by the Wall Street Journal reported that "As part of efforts to reduce traffic congestion during the 2008 Olympic Games, the city of Beijing is forming an unusual technology partnership with Nissan Motor Co. to install a citywide navigation system (Chozick, 2007).” (Verma, 2005)

\section{OUTSOURCING TO INDIA: STRENGTHS \& OPPORTUNITIES}

The software and ITES (information technology enabled services) exports from India grew from US\$12.9 billion in the year 2003-04 to US\$23.6 billion in 2005-06. It is estimated that the total software and ITES exports from India will exceed US\$ 31.3 billion during the year 2006-07. Software and services exports are likely to beat forecasts and exceed 32\% in dollar terms during the year 2006-07 (Department of Information Technology, India, 2007). The offshore outsourcing sector employed nearly 700,000 people in 2005, according to the McKinsey Global Institute. By 2007-08, that workforce will consist of about 1,450,000 to 1,550,000 people, and the industry will account for 7 percent of India's GDP (McKinsey, 2007).

In 2007, the AT Kearney study listed the top 50 global outsourcing destinations based on cost, people skills and availability, and business environment. India again was at the top, with a diminishing but still large lead over China in second place. The report says India's dominance is due to an "unbeatable mix" of low costs, deep technical and language skills, mature vendors and supportive government policies. It adds that wage inflation has been matched by corresponding increases in the supply and quality of skills (Business Week, 2007). Even with the wage of Indian engineers is rising, outsourcing to India remains a cost-effective choice because of the advancement in technology, process control, and the quality of products and services that companies offer. Although the Indian IT industry has the largest share in the IT outsourcing market, it gained only $2 \%$ of its revenue from Japan. Considering the fact that Japan has the second largest IT market (JISA, 2007), Indian companies have not been able to explore the huge opportunity.

In India, as much as 85 companies reached the highest level (Level 5: Optimizing) of Capability Maturity Model Integration (CMMI) (JISA, 2007). The fact that more than $80 \%$ of Level 5 certified companies are Indiabased proves that Indian companies possess the world-best skills of project management and quality control. Therefore, objectively, India should be the most attractive offshore location for quality-sensitive clients.

In India, more than 25 companies employ over 5,000 workers, while only 5 companies employ more than 2,000 workers in China (75\% of software companies in China employ less than 50 people.) (Okawa, 2005). More companies are ready for large projects with experienced project managers and programmers in India. Larger companies are also more capable of attracting, developing and retaining workers because they tend to attract more interesting and longer-term projects, provide better training opportunities, and offer more generous incentives (Filippo and Ip, 2005).

India's pool of young university graduates is estimated at 14 million -the largest of all 28 countries MGI has studied (McKinsey, 2007). Based on the data of US census and NASSCOM, the number of new graduates who acquired engineering degree in 2003 was 292,000 in India, 195,000 in China, 103,000 in Japan, 82,000 in Russia, 61,000 in the US, and 45,000 in South Korea (JISA, 2005). The large number of English speakers is also one of the major reasons why the US and European companies choose India as offshore destination. Another advantage of Indian companies is that they can divide up a project, assign each part to the appropriate engineers, assure the 
quality, reassemble the parts, and export the finished product. Executives of Indian companies believe that this highly sophisticated development method enables them to win competitions with local companies outside India (Kitagawa, 2007).

The major Indian multinationals have branches overseas including in Japan and in China. They believe in their ability to coordinate global \& local staff in each location. By using the services provided by those Indian multinationals, Japanese companies could benefit from their top-level quality and technology while being supported by Japanese staff. This could happen without needing to actually going to India and setting up operations by their own.

\section{COMPARATIVE EVALUATION OF CHINA AND INDIA}

\section{Areas of Competence}

China appears to be the best destination for Japanese companies that wants to outsource small projects. In addition, Chinese companies have significant strength in embedded software development, coupled with their general success in the manufacturing sector. According to the Organization for Economic Co-operation and Development (OECD), China surpassed the United States as the world's top exporter of laptop computers, mobile phones and other ICT (information and communications technology) devices in 2004 (OECD, 2006). On the other hand, Indian companies have excellent reputation for are in high repute in the area of large system development, middleware package software production, customizing, and system consulting.

\section{Culture and Values}

The Chinese Society is relatively homogeneous. Even though there are numerous dialects, $95 \%$ of the population is the Han Chinese, and most of them use one written language (Mandarin). There are many similarities between the Chinese and Japanese language and that makes it easier for them to understand some of the programming difficulties. On the other hand, the ethnic and linguistic diversity of India's civilization with more than 15 recognized languages and an estimated 1,600 spoken dialects is astounding. There are vast numbers of different regional, social and economic groups, each with different cultural practices (Bhasin, B. 2007).

\section{Labor Costs}

The monthly wage paid to local engineers by Japanese companies in Shanghai, China was $\$ 121$ - \$266 in 2004, while it was \$250- \$408 in New Delhi, India (Iwami, 2005). Even though the wage in China is rising, it is still cheaper than in India. As more and more companies see the opportunities to outsource business to India, they have to compete for limited talents. In India, if an IT related employees feel that they are underpaid, they are often able to find another employer which offers higher salaries and fringe benefits without much difficulty. According to the research conducted by IDC India in September 2007, salaries of India's software professionals rose at an average of $18.7 \%$ and reached $\$ 15,300$ (Kitagawa, 2007). Rising wages have become serious concern in India. For example, Apple "walked away" from India in 2006. It is said the reason was that India wasn't as inexpensive as it used to be. The high turnover ratio and the competition for good people were other concerns (Kripalani and Burrows, 2006).

Despite these issues, India has a general advantage over China in terms of offshore software development experience and achievement with U.S. clients. This could be a merit for Japanese companies which operate globally, because by forming a business partnership with Indian company, they can compete more effectively in the global market. A consultant from TATA Consultancy Services (TCS) says that more and more Japanese IT subsidiaries of financial and manufacturing sectors are visiting the head quarters of TCS, exploring the opportunities of offshore relationships. For example, Sony makes India its base of software development. For Kyocera, India is the second most important cell phone software development base after the US. NEC conducts training of new Japanese employees in India in order to acquire the most advanced IT skills. IBM Japan outsources to India some of their software development projects which awarded by Japanese customers. (TATA Consultancy Services, 2005). 


\section{CONCLUDING REMARKS}

India will keep the top position as the most favorable global outsourcing destination. A McKinsey study of China's software sector anticipates that many years will pass before China poses a major threat to India (Filippo and Ip, 2005). Although Indian companies now focus on business with U.S. and Europe, as they see more opportunities in the Japanese outsourcing market, the competition between China and India will become fiercer. However, it is unlikely that Japanese companies will quickly shift their offshore destination from China to India. It takes some time for Indian companies to train their employees, while most of the small Japanese companies do not have English speaking employees.

It is clear that Indian companies will have more business opportunities with large Japanese corporations that seek large-scale development resources, higher quality of products and services, system design and consultation services. A new are of development is the growing activities between India and China. IT companies in China and India see new opportunities of doing business in each other's country. Since Chinese companies are trying to learn advanced technology and process controls from India, training courses offered in India are becoming popular. Large Indian companies such as Tata Consultancy Services are building software development teams in China. One reason is to use China as a base to win business from Japan and South Korea. Secondly, the Indians also hope to explore low-cost areas in different parts of the country, such as the western cities of Xian and Chengdu (Einhorn and Lakshman, 2006).

The unique cozy relationships among Japanese companies have sometimes hindered them from establishing rational processes and criteria for software development and project management. However, the old approach will not work well for long in offshore outsourcing. To assure good outcomes and prevent various difficulties, it is important to agree on and stipulate items such as the scope of the project, schedule, role and responsibility of vendor, ownership of products, confidentiality, minimum service level, payment, and penalty for violation. It is clear that now that Japanese companies have to rely more on offshore outsourcing, they will eventually need to break away from the current practices.

China has provided a good location that represents a gradual transition away for long trusted domestic relationships and business practices to one where language and cultural similarities makes it easier to relinquish control over certain aspects of their software development processes. This is especially important for small and medium-sized Japanese firms that lack global staff and capabilities. However, the larger Japanese firms appear to be focusing on a more rational allocation of the business process. Their outsourcing experiences and knowledge should eventually influence the smaller companies as successful outsourcing models emerge.

In the future, Japanese companies will try to diversify their offshore destinations to avoid risks. Those risks include fluctuation of currency, rising wages, shortage of engineers, natural disasters, and political instability. In terms of international borders, relationships between customers and vendors will become more multilateral and dynamic.

\section{AUTHOR INFORMATION}

Roblyn Simeon is a professor of international business at San Francisco State University. He has taught a wide range of courses related to international business. His main areas of research include internet marketing strategies, popular culture dynamics, comparative business strategies, organizational behavior, career management and emerging market strategies. In addition to having been involved in many executive training and management consulting projects, Professor Simeon has also worked on Wall Street and in Tokyo as a financial and securities analyst. He is fluent in five languages and has lived in and traveled extensively in Europe, South America, and Asia.

\section{REFERENCES}

1. Asahi-Shinbun (July 9, 2007) Editorial: Japan's war with China

2. Asami, N (April 23, 2007) Age-old problem, software crisis, IT Pro 
3. Atmark IT (2005, September 10) The lowest level of new IT investments by Japanese companies, Retrieved May 1, 2007, from http://www.atmarkit.co.jp/news/200509/10/forrester.html

4. Bhasin, B. (2007), Cross Cultural Management: An International Journal, Retrieved November 15, 2007 from http://www.emeraldinsight.com/Insight/viewContentItem.do;jsessionid=5BAA759CF2F31A152D2BE1307 35AD593? content Type $=$ Article\&contentId $=1593230$

5. Business Software Alliance (May 2005) Piracy Study, Retrieved May 1, 2007, from http://www.bsa.org/globalstudy/upload/2005-Global-Study-English.pdf

6. $\quad$ Business Week (March 20, 2007) China, India Seen Dominating Outsourcing.

7. Chozick, A (July 31, 2007) Nissan Pairs With Beijing On System to Avoid Jams, Wall Street Journal

8. Department of Information Technology, Ministry of Communications \& Information Technology (Govt. of India) (2007) Annual report 2006-2007.

9. Economist.com (AUGUST 22, 2005) A New World Economy: The balance of power will shift to the East as China and India evolve Retrieved November 25, 2007, from http://www.businessweek.com/magazine/content/05 34/b3948401.htm

10. Economist.com (July 26, 2007) China's economy: It doesn't add up, Retrieved November 24, 2007, from http://economist.com/finance/displaystory.cfm?story id=9552969

11. Einhorn, B. and Lakshman, N. (November 14, 2006) Patience Is Virtue in China, India IT Learns Retrieved May 1, 2007, from http://www.businessweek.com/globalbiz/content/nov2006/gb20061114 537994.htm

12. $\quad$ Farrell, C. (2005). "An Onshore Play In Offshoring." Business Week(3931): 90.

13. Filippo, G. and Ip, C. (2005) Can China compete in global IT outsourcing?, McKensey on IT, Retrieved November 27, 2007, from www.mckinsey.com/clientservice/bto/pointofview/pdf/MoIT4_ChinaOuts.pdf

14. Gefen, David; Carmel, Erran (2008). "Is the World Really Flat? A look at offshoring at an online programming marketplace". MIS Quarterly. Volume 32, Issue 2: p. 367.

15. Gottschalk, P. and H. Solli-Sæther (2005). "Critical success factors from IT outsourcing theories: an empirical study." Industrial Management + Data Systems 105(5/6): 685.

16. Gottschalk, P. and H. Solli-Sæther (2006). "Maturity model for IT outsourcing relationships." Industrial Management + Data Systems 106(1/2): 200.

17. Hall, R. (2000). "The management of external resources." Journal of General Management 26(1): 56.

18. Hiragana Times, Japan-Behind the Scenes - Japanese Society /Politics, retrieved April 28, 2007, from http://www.hiraganatimes.com/hp/scenes/kiji/kiji230-1e.html

19. Ai Agency (March 2007) News in India March 2007, Retrieved May 1, 2007, from http://www.indjpn.com/indnews0703.html

20. ITPro (2007) Vulnerability of Japanese IT industry, retrieved April 25, 2007, from http://itpro.nikkeibp.co.jp/as/saas/special/03.shtml

21. Iwami, M. (September 14, 2005) India is expected to be a large market, Shinkin Central Bank, Retrieved May 1, 2007, from http://www.scbri.jp/PDFasiagyou/scb79h17q041.pdf

22. Japan Foundation (2005) Information of Nihongo education by country: China, Retrieved May 1, 2007, from http://www.jpf.go.jp/j/japan_j/oversea/kunibetsu/2005/china.html

23. JASSO (Japan Student Services Organization) (December 13, 2006) International Students in Japan.

24. JEITA (Japan Electronics and Information Technology Industry Association) and Accenture (October 30, 2006) The research, analysis and suggestion regarding software offshore development by foreign/domestic companies, Retrieved May 1, 2007, from http://it.jeita.or.jp/infosys/committee/software/061030/index.html

25. JEITA (Japan Electronics and Information Technology Industry Association), JPSA (Japan Personal Computer Software Association), and JISA (Japan Information Technology Services Industry Association) (July 2005) Survey of Overseas Transactions and Employment of Foreigners in Japan, Retrieved April 12, 2007 from www.jisa.or.jp/pressrelease/2005-1019.html

26. JISA (Japan Information Technology Services Industry Association) (2003), Research report regarding international software trading of domestic companies and the industry trend of IT service in foreign countreis, Retrieved May 1, 2007, from http://www.jisa.or.jp/report/2003/15-J012.pdf

27. King, W. R. (2005). "Outsourcing and Offshoring: The New IS Paradigm?" Journal of Global Information Technology Management 8(2): 1. 
28. Kitagawa, K (June 2, 2006) Go for global delivery after reaching 100 billion Yen, Learn from the system of manufacturing industry, ITPro, Retrieved May 1, 2007, from http://itpro.nikkeibp.co.jp/article/COLUMN/20060929/249409/

29. Kitagawa, K (November 6, 2007) Outsourcing: Leaving India, ITPro, Retrieved November 24, 2007, from http://itpro.nikkeibp.co.jp/article/COLUMN/20071029/285769/

30. Koong, K. S., L. C. Liu, et al. (2007). "Taxonomy development and assessment of global information technology outsourcing decisions." Industrial Management + Data Systems 107(3): 397.

31. Kripalani, M. and Burrows, P. (June 19, 2006) India: Why Apple Walked Away, BusinessWeek.

32. McFarlan, W.and DeLacey, B. (2004) Outsourcing IT: The Global Landscape in 2004, Harvard Business School Case NO. 304-104, 2004

33. McCoy, M. (2006). "DISCOVERING JAPAN." Chemical \& Engineering News 84(20): 29.

34. McKinsey (2007) Ensuring India's offshoring future, Retrieved May 5, 2007, from http://www.mckinseyquarterly.com/article_abstract.aspx?ar=1660\&L2=1\&L3=106\&srid=17\&gp=0

35. METI- Ministry of Economy, Trade and Industry, Japan (2004) Overview of the Information Services Business, Retrieved May 1, 2007, from http://www.meti.go.jp/english/statistics/tokusabi/2004k-e/h16-gai02.pdf

36. METI- Ministry of Economy, Trade and Industry, Japan (2006) Survey of embedded software industry, Retrieved November 13, 2007, from https://sec.ipa.go.jp/download/files/report/200706/ebtrainbp20070612.pdf

37. Ministry of Internal Affairs and Communications, Japan (2007), White Paper: Information and Communications in Japan 2007 Retrieved November 20, 2007 from http://www.johotsusintokei.soumu.go.jp/whitepaper/ja/h19/index.html

38. Montes, S. and B. Kleiner (2007). "Technological issues and organisational culture in the automotive industry." International Journal of Technology Policy and Management 7(1): 68.

39. Nagayama, T. (2006). "Measures to Improve Workforce Efficiency in Japanese Small and Medium-sized Businesses and their Effectiveness." Asian Business \& Management 5(4): 529.

40. National University of Singapore (2007), India: Religion and Philosophy, Retrieved November 24, 2007, from http://www.scholars.nus.edu.sg/post/india/religion/religionov.html

41. OECD (November 20, 2006) OECD finds that China is biggest exporter of Information Technology Goods in 2004, surpassing US and EU Retrieved November 21, 2007, from

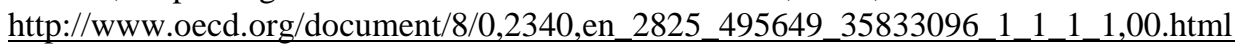

42. Okawa, J. (February 15, 2005) The current situation of Indian IT industry and the secrets of growth, Mycom Journal.

43. Satyam Computer Services Ltd (2007), About Satyam, Retrieved November 24, 2007, from http://www.satyam.co.jp/aboutsatyam/a_aboutus.html

44. Software Engineering Institute (2007) What is CMMI?, Retrieved on May 5, 2007 from http://www.sei.cmu.edu/cmmi/general/general.html

45. Straub, Detmar; Weill, Peter; Schwaig, Kathy (2008). "Strategic Dependence on the IT Resource: a test of the strategic control model”. Information Systems Frontiers. Vol. 10, Issue 2: 195-216.

46. TATA Consultancy Services (March 23, 2005) Getting popular in Japan; Offshore development commission, IT Media.

47. Tech Soken (March 21, 2007) Break the bad custom of IT companies, Retrieved May 1, 2007, from http://japan.cnet.com/tech_life_and_work/001026.htm

48. Tomiura, E. (2005). "Foreign outsourcing and firm-level characteristics: Evidence from Japanese manufacturers." Journal of the Japanese and International Economies 19(2): 255.

49. Verma, R. (June 17, 2005) China's rise: IT's not a problem for India, Asia Times Online, Retrieved November 24, 2007, from http://www.atimes.com/atimes/South_Asia/GF17Df01.html

50. Waldenberger, F. (2007). "Growth and Structural Change in the Japanese Economy 1985-2000: An InputOutput Analysis." Asian Business \& Management 6(1): 15.

51. Welch, J and Welch,S (March 2007) Choosing China or India; Here's a way to figure out which, if either, is right for your business, BusinessWeek

52. World Bank, the (2005) Data and Statistics

53. Wright, Robyn (April 2005) Successful IT Outsourcing: Dividing Labor for Success, Retrieved November 27, 2007, from http://www.softwaremag.com/l.cfm?doc=2005-04/2005-04outsourcing 
54. Xing, L. (November 20, 2006) Chinese, Indians share similarities, ChinaDaily.

55. Xinhua (April 13, 2007) China becomes Japan's biggest software outsourcing base, Retrieved November 24, 2007, from http://news.xinhuanet.com/english/2007-04/12/content 5968762.htm

56. Yamanoi, S (January 2, 2004) Outlook of 2004: Slow growth era of Japanese IT service market, Gartner Research Japan, Retrieved May 1, 2007, from

http://japan.cnet.com/news/ent/story/0,2000056022,20063445,00.htm

\section{NOTES}

